\title{
Printers' Devices as Decorative Elements in Library Architecture
}

\section{Citation}

Nipps, Karen. 2013. “Printers' Devices as Decorative Elements in Library Architecture." The Library Quarterly 83 (3) (July): 271-278. doi:10.1086/670701.

\section{Published Version}

doi:10.1086/670701

\section{Permanent link}

http://nrs.harvard.edu/urn-3:HUL.InstRepos:17219055

\section{Terms of Use}

This article was downloaded from Harvard University's DASH repository, and is made available under the terms and conditions applicable to Other Posted Material, as set forth at http:// nrs.harvard.edu/urn-3:HUL.InstRepos:dash.current.terms-of-use\#LAA

\section{Share Your Story}

The Harvard community has made this article openly available.

Please share how this access benefits you. Submit a story.

\section{Accessibility}




\section{Printers' Devices as Decorative Elements in Library Architecture}

\section{Karen Nipps}

But O the truth, the truth! the many eyes

That look on it! the diverse things they see!

(George Meredith, A Ballad of Fair Ladies in Revolt [1903])

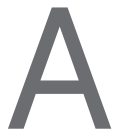

$\mathrm{s}$ has been described in the editorials of the past two issues, The Library Quarterly has changed in appearance and content to better reflect contemporary research on library-related issues. As the newly dubbed "History of the Book" editor, I am excited that the cover article segment of the journal is being expanded to acknowledge the growth of book history as its own discipline, replete with its own complexity, ambiguity, richness, and pertinence. The connection between the study of printers' and publishers' devices and library research may have seemed tenuous at times, but there is no arguing that the histories of books and libraries are closely conjoined. Moreover, it is the conviction of many that these studies and the future of libraries are inexorably entwined. The subject of this month's feature demonstrates this inseparability. It also pays homage to the significant contributions to book history made by previous authors' with their work on printers' devices and hints at some of the variety readers of this segment will encounter in the future.

"American Craftsman" denotes a style of architecture, interior design, and decorative arts that was particularly popular in the United States between 1910 and 1925. (Revivalists continue to promote it.) Its origins were in the British Arts and Crafts movement, which itself sought to depart from the dehumanizing effects of the Industrial Revolution and the opulence of Victorian society. They both stood for traditional craftsmanship in all creative endeavors, emphasizing hand-made over machine-made, a simplicity in form, and decorative themes that harkened back to medieval, romantic, and folk styles.

Library Quarterly: Information, Community, Policy, vol. 83, no. 3, pp. 271-278. (c) 2013 by The University of Chicago. All rights reserved. $0024-2519 / 2013 / 8303-0009 \$ 10.00$ 
American library construction of the time, which was extensive due to an economic boom, reflects these aspirations. Architects and designers applied them in ways both grand and subtle. One motif particularly well suited to both private and public library design was that of printing history, and printers' devices are used repeatedly to decorate windows, ceilings, walls, detailing, and exteriors. As a January 1909 article in American Homes and Gardens on "Colored Windows in the House" opined, "In the library the subject is of paramount importance and a great range of motives [sic] exist from which selection can be made; book marks, printers' devices, emblems of the crafts relating to book making, printing and illustrating, seals of great libraries and universities, etc." (30). In the June 1915 issue of the Industrial-Arts Magazine, Irene Warren, librarian at the School of Education at the University of Chicago, described the redesign of the university's high school library in "Printers' Marks as Mural Decorations in a High School Library." She explained: "As librarians we are always watchful for opportunities to emphasize to our young people the dignity and beauties of the arts and crafts involved in book-making. When the shelving [for the new library] was constructed at the correct height, against one of the walls, it left a bit of Gothic structure above. We asked the head of the Art Department to change this ugly space for us and he did so with a very pleasing series of color decorations, using the printers' marks as shown" (272).

The virtuous, hardworking, creative, entrepreneurial printers of earlier centuries (as so idolized) provided inspiration to young and old alike. No less than the Tiffany shop produced numerous exquisite murals of colored glass honoring the great Gutenberg - these can now be found spread across this country from coast to coast in libraries of every type and dimension. The selection of printers' devices shown here in no way indicates a preference for them. Indeed, what turns out to be so entertaining once one embarks on a search for examples is to discover how very many and various they are. Have a look for yourself. (See figs. 1-8; see the appendix in the online version of this article for additional illustrations.) 


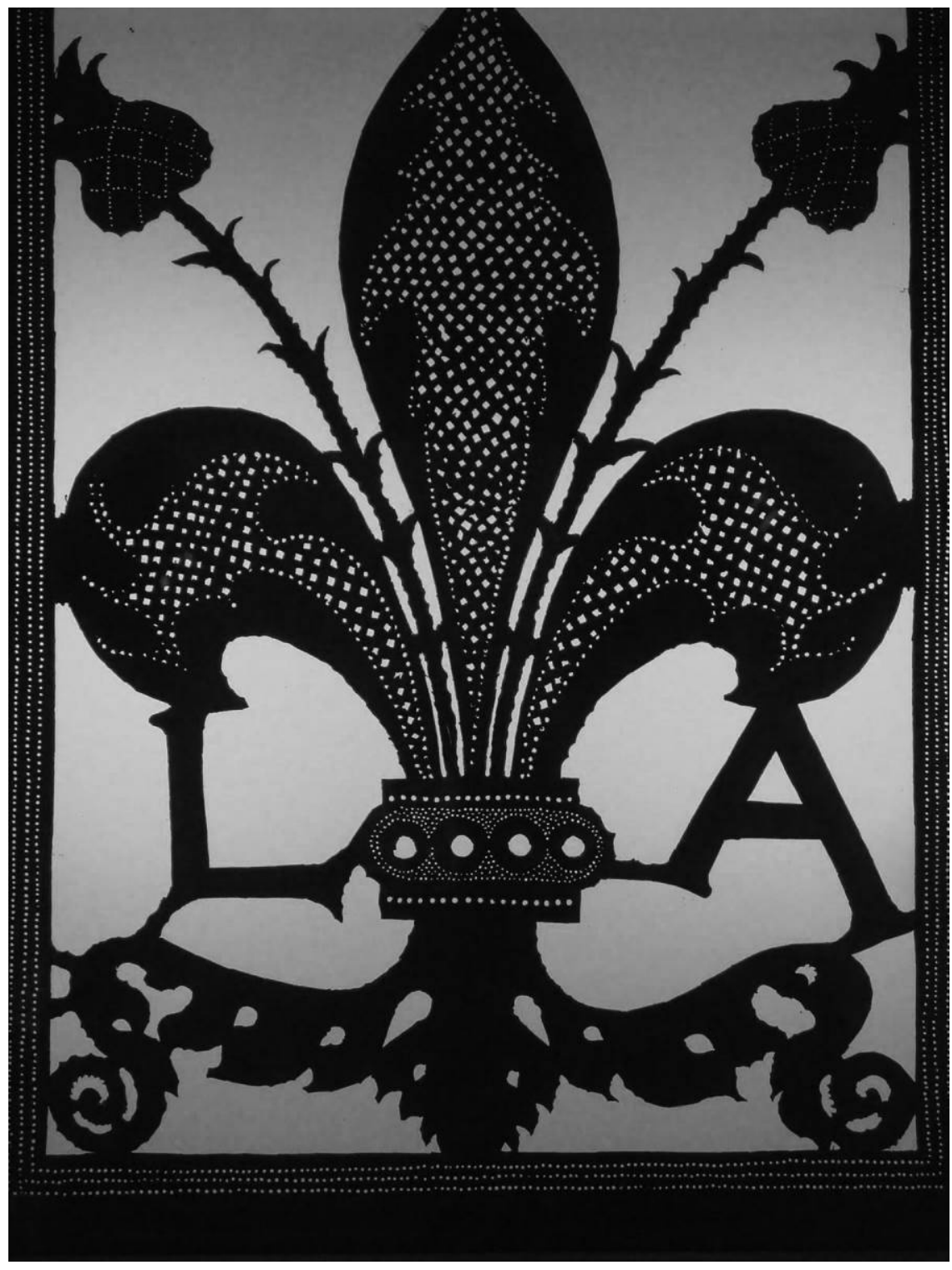

Figure 1. Device of Luca-Antonio Giunta of Venice, Mansueto Library, University of Chicago. Originally from the R. R. Donnelley Calumet Plant (1912-29). 


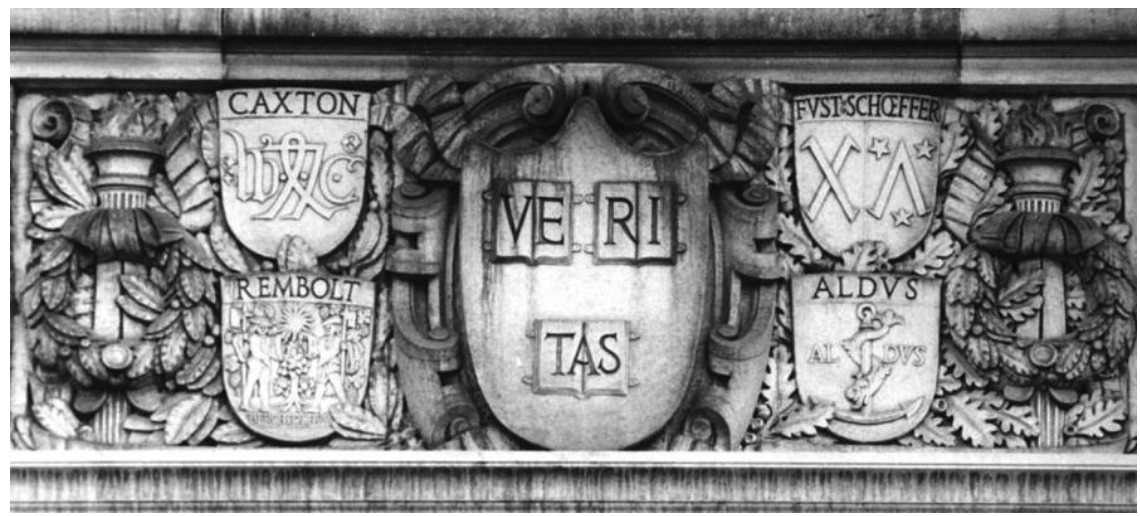

Figure 2. Devices (from top left clockwise) of William Caxton, Fust \& Schoeffer, Aldus Manutius, and Berthold Rembolt, Widener Library, Harvard University. Completed 1915.

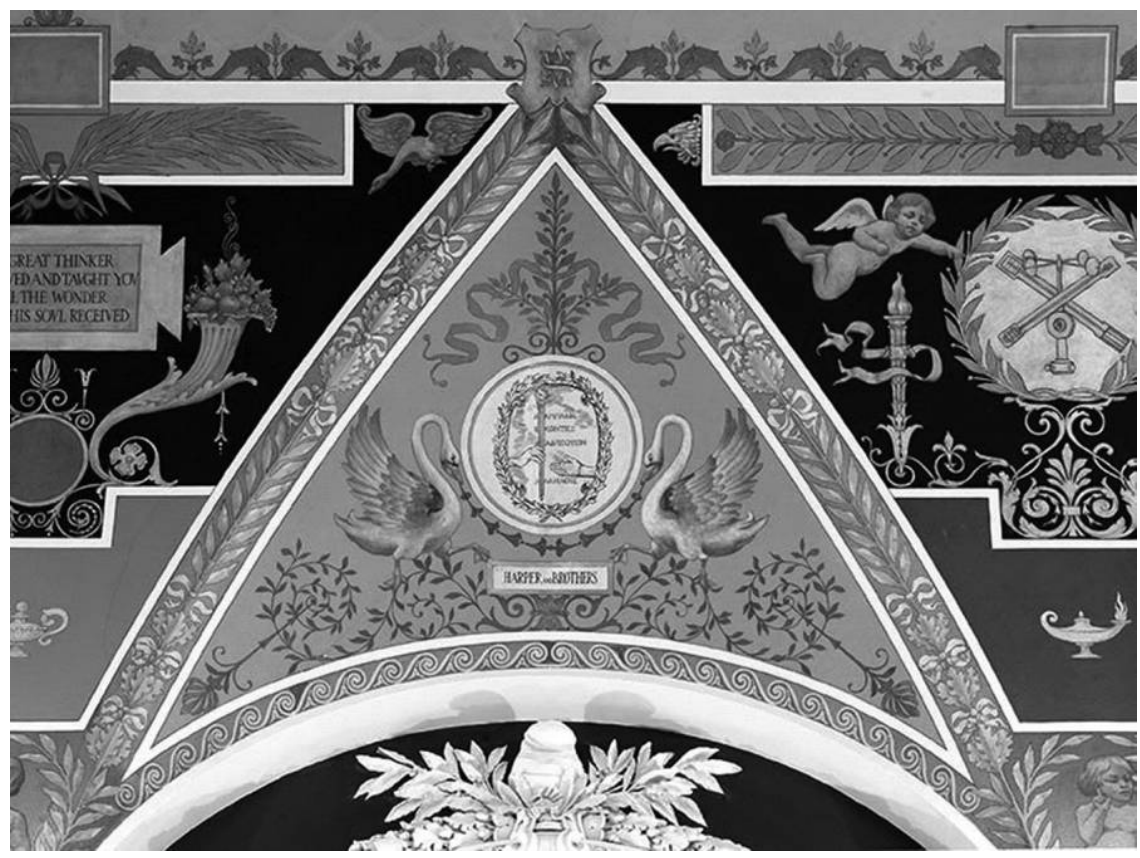

Figure 3. Device of Harper \& Brothers in New York, Thomas Jefferson Building, Library of Congress. Completed 1897. A color version of this figure is available online. 


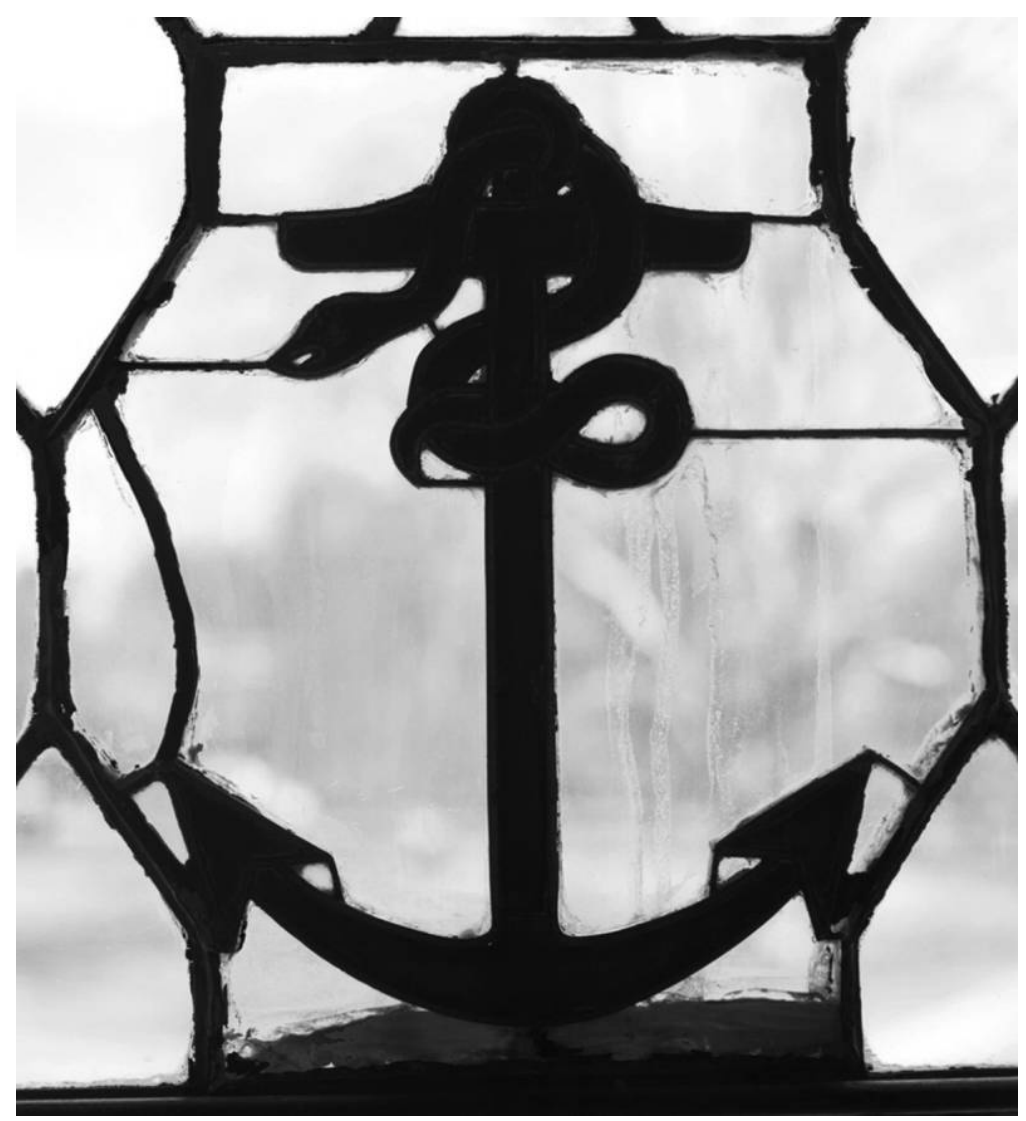

Figure 4. Device of Jean Crespin of Geneva, Frederick Ferris Thompson Memorial Library, Vassar College. Completed 1905. 


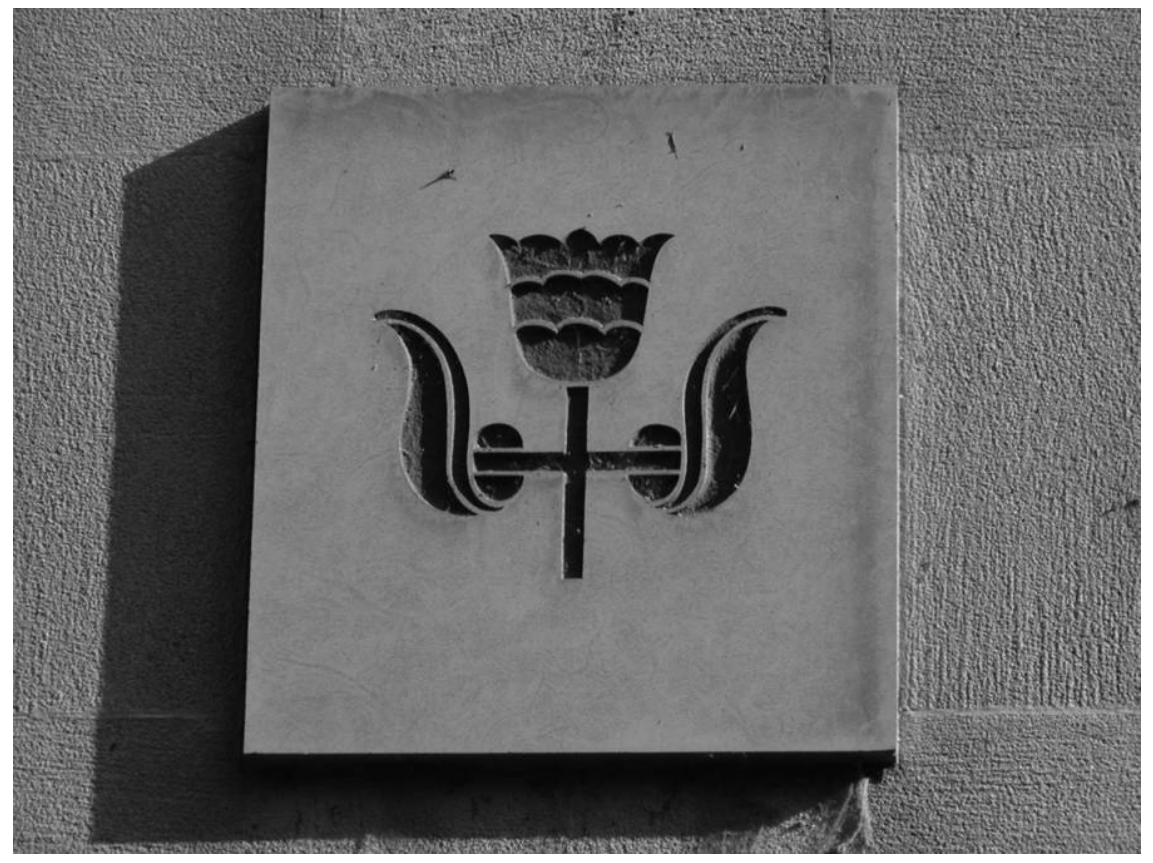

Figure 5. Device of Ottaviano Scotto of Venice, Allen Hall, University of Oregon. Completed 1954. Edward H. Teague, The Architecture of the University of Oregon, October 10, 2004, from the University of Oregon Library site, http://www.library.uoregon.edu/guides/architecture/oregon/. 


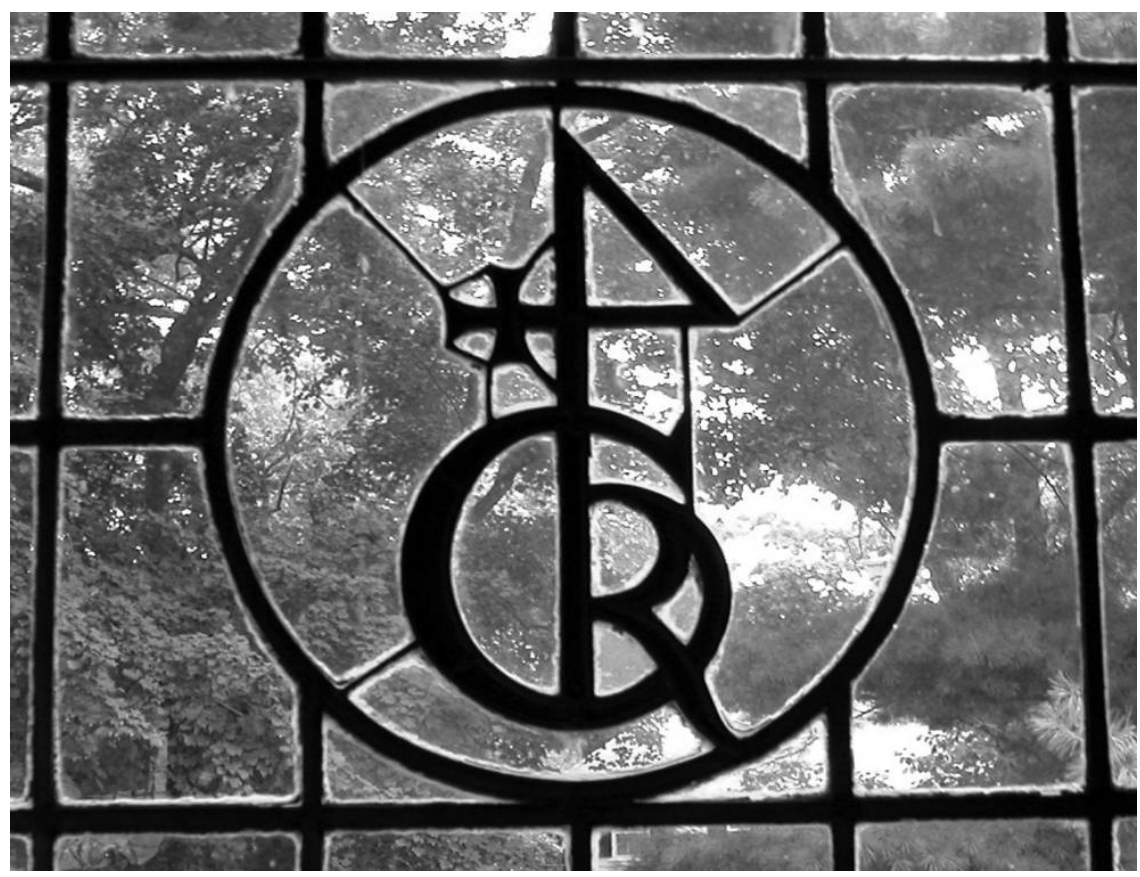

Figure 6. Device of Richard Grafton of London, Andover Hall (originally the Moses Stuart Reading Room), Harvard Divinity School. Completed 1911. A color version of this figure is available online.

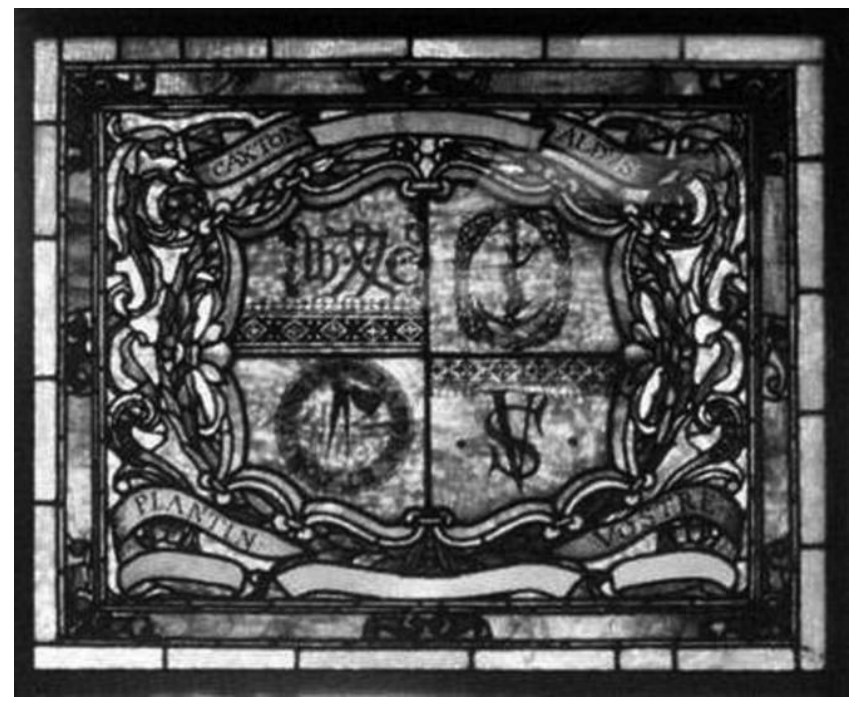

Figure 7. Devices (from top left clockwise) of William Caxton, Aldus Manutius, Simon Vostre, and Christophe Plantin, Morrisson-Reeves Library, Richmond, IN. Installed ca. 1893. A color version of this figure is available online. 


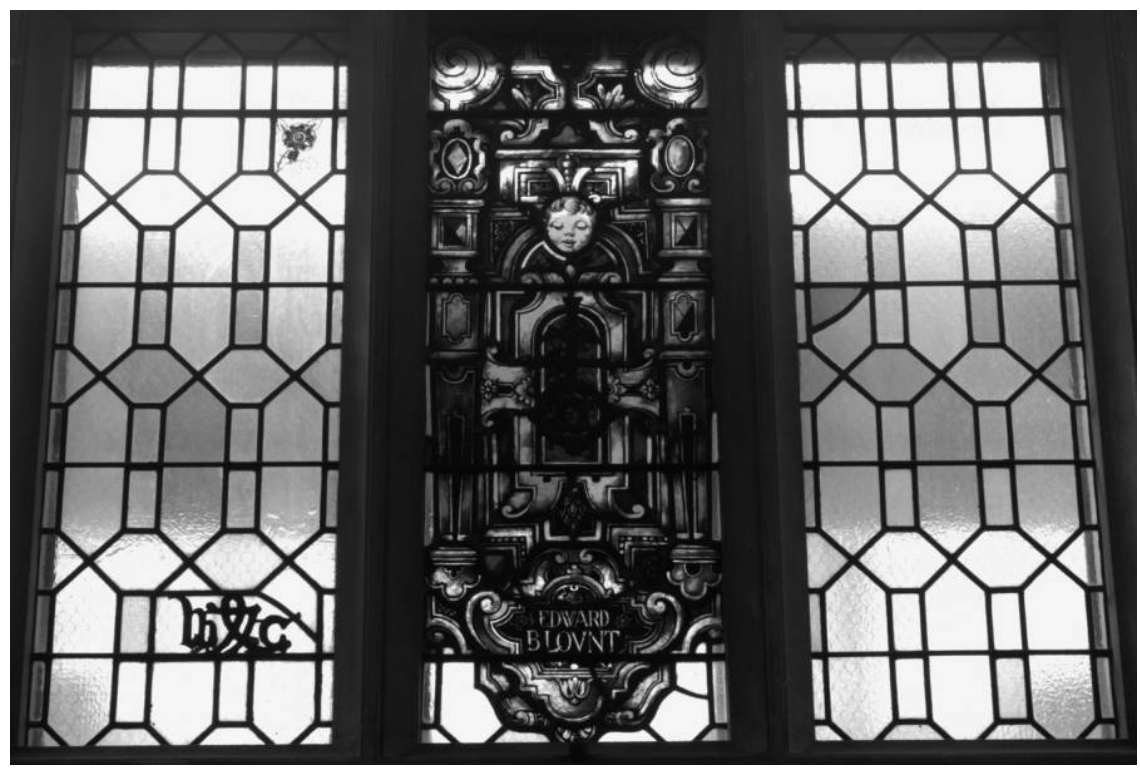

Figure 8. Device of William Caxton. Paster Reading Room stained glass window. Courtesy of Folger Shakespeare Library. Completed 1932. A color version of this figure is available online.

Karen Nipps: head of the rare book team at Houghton Library, Harvard University. As the cover editor for The Library Quarterly, she has written on a number of printers and their devices, ranging from Aldus Manutius in fifteenth-century Italy to William Rudge in twentieth-century America. She has just published a lengthy study of the nineteenth-century Philadelphia printer Lydia Bailey, entitled Lydia Bailey: A Checklist of Her Imprints (University Park: Pennsylvania State University Press; ISBN 978-0-271-05571-8). E-mail: nipps@fas.harvard.edu. 